\title{
ON THE NORMATIVE CONNECTION BETWEEN PATERNALISM AND RIGHTS
}

\author{
Stephanie Sheintul
}

$\square^{1}$ OME SCHOLARS working on the ethics of paternalism are interested in whether there is a systematic normative connection between hard paternalism and people's moral rights. This discussion understands hard paternalism as paternalism that takes place between competent adults, i.e., "human beings in the maturity of their faculties." 1 One affirmative view is that hard paternalism is pro tanto wrong inasmuch as it always involves a rights violation. ${ }^{2}$ Daniel Groll defends this view on the grounds that hard paternalism always violates a competent adult's right to be the only one to act only (or overridingly) for his own good. ${ }^{3}$ I call this right the right to self-beneficence.

I argue that Groll misidentifies a right that competent adults have. Rather than the right to self-beneficence, I argue that if hard paternalism violates any particular right, it is a right that a competent adult has against others "taking over" matters that fall within his sphere of legitimate agency or, by extension, the legitimate exercise of his agency. Following George Tsai, "taking over" can consist of an agent interfering with, intruding on, circumventing, supplanting, replacing, or ignoring the legitimate exercise of another's agency. ${ }^{4}$ I call this right the right against legitimate agency interference. ${ }^{5} \mathrm{I}$ am agnostic about whether competent adults actually have this right. But if there is a systematic normative connection between hard paternalism and people's rights, it is in virtue of violating the proposed right.

Three preliminary remarks are in order. First, understanding what paternalism involves is controversial. ${ }^{6}$ For present purposes, I understand paternalism

1 Mill, On Liberty, 9. Hereafter, all referenced individuals are competent adults.

2 Groll, "Paternalism and Rights," 124.

3 Groll, "Paternalism and Rights," 124. Hereafter, I use the term "primarily" in place of "overridingly."

4 Tsai, "Rational Persuasion as Paternalism," 87. I added "ignoring" to the above list.

5 Though I use the term "interference" in naming this right, any of the terms in the list above can stand in for it.

6 For an overview of this debate, see Begon, "Paternalism." 
as follows. $A$ acts paternalistically toward $B$ if and only if $A$ takes over a matter that falls within $B$ 's sphere of legitimate agency or, by extension, the legitimate exercise of $B$ 's agency, and is motivated by a distrust of $B$ 's agency and a concern for B's good. ${ }^{7}$

Second, while Groll has little to say about the nature of the right to self-beneficence, I find it most charitable to understand this right as a claim right. On Wesley Hohfeld's influential account of claim rights, a person's claim right always generates a correlative duty in at least one other person. ${ }^{8}$ Accordingly, the right to self-beneficence generates a duty that others refrain from acting only or primarily for another's good. Relatedly, the right to self-beneficence should be understood as a pro tanto claim right. According to Danny Frederick, "a right is pro tanto if and only if there are exceptional circumstances in which it is permissible to infringe it, even though it is impermissible to infringe it in normal circumstances." ${ }^{\prime \prime}$ Conceptualizing the right to self-beneficence as pro tanto allows for the possibility that, under certain circumstances, it is permissible for an agent to act only or primarily for another's good. ${ }^{10}$

Third, in light of understanding this right as a pro tanto claim right, I jettison the language of "rights violation." The view that Groll defends should be reconceived as follows: hard paternalism is pro tanto wrong inasmuch as it always involves a rights infringement. For Groll, this view is true in virtue of hard paternalism always infringing a person's right to self-beneficence. I argue, however, that if this view is true, it is in virtue of hard paternalism always infringing a person's right against legitimate agency interference.

\section{THE RIGHT TO SELF-BENEFICENCE}

According to John Stuart Mill, "in the part [of his conduct] which merely concerns himself, [a person's] independence is, of right, absolute." ${ }^{11}$ Drawing from Mill, a person might be thought to have a claim right against others interfering in his self-regarding matters. Or, drawing from Joel Feinberg, a person might be thought to have a right to autonomy, understood as a right against others inter-

7 I draw from George Tsai and Seana Shiffrin in articulating this understanding of paternalism. See Tsai, "Rational Persuasion as Paternalism," 88; and Shiffrin, "Paternalism, Unconscionability Doctrine, and Accommodation," 218.

8 Hohfeld, Fundamental Legal Conceptions.

9 Frederick, "Pro-Tanto Versus Absolute Rights," 375.

10 Groll suggests this much in claiming that people are sometimes morally authorized to act only for another's good. See Groll, "Paternalism and Rights," 124-26.

Mill, On Liberty, 9. 
fering with matters that fall within his private realm. Choices that fall within this realm must not directly violate the interests of others. ${ }^{12}$

As Groll discusses, both of these rights are difficult to conceptualize. A worry with the Millian right is that there are few actions that are self-regarding. Similarly, a worry with the Feinbergian right is that it is difficult to identify the boundaries between the private realm and the public realm. ${ }^{13}$ These difficulties might lead one to worry that any attempt to carve out a sphere of choices over which a competent adult is sovereign will result in conceptual complications. ${ }^{14}$

In light of this consideration, Groll suggests that a dialectic shift is in order. Rather than focus on what an agent is interfering with, one should instead focus on "why an agent is doing whatever he is doing."15 According to Groll, a competent adult is sovereign when it comes to acting for a particular reason, namely, only or primarily for the sake of his good. If an agent acts only or primarily for the sake of his good, then she infringes his right to self-beneficence.

To help illustrate how hard paternalism infringes this right, Groll offers the following case.

Rob's Keys: Fatima loves listening to loud, live music. This has taken a toll on her hearing. Her doctors have told her that if she doesn't start wearing earplugs to shows, she may well lose her hearing altogether in the coming year. Fatima has ignored their warnings to this point. Tonight, Napalm Death is in town and Fatima is keen to go. Her friend, Rob, is very concerned about Fatima's hearing. The only way for Fatima to get to the concert is to borrow Rob's car. Rob knows that she'll take the car whether he gives her permission to or not, so he hides his keys, thereby preventing her from making it to the concert. ${ }^{16}$

According to Groll, Rob acts wrongly in virtue of infringing Fatima's right to self-beneficence. Rob infringes this right by hiding his keys from Fatima primarily because he wants to prevent her from ruining her hearing. If Rob's primary reason for hiding his keys was that he did not want Fatima to use the rest of the gas in his tank, then he would not have infringed her right to self-beneficence.

12 Feinberg, The Moral Limits of the Criminal Law.

13 Groll, "Paternalism and Rights," 124.

14 Though carving out such a sphere may be difficult, doing so is not insurmountable. If hard paternalism infringes a particular right, then constructing a person's "sphere of legitimate agency" is required to properly understand this right.

Groll, "Paternalism and Rights," 124.

Groll, "Paternalism and Rights," 122. 
But since his primary reason for acting is his concern for Fatima's hearing, Rob infringes this right.

\section{THE GIFT-GIVING OBJECTION}

To its credit, the right to self-beneficence is not as difficult to conceptualize as either the Millian right or the Feinbergian right discussed above. Nevertheless, it generates the counterintuitive implication that, in an ordinary instance of gift giving among competent adults the gift giver, in acting only or primarily to make the gift recipient happy, infringes his right to self-beneficence. I call this the gift-giving objection.

Groll acknowledges and responds to this objection. He writes:

The general answer to [the gift-giving objection] is that ... there is normally a presumption that our benevolent actions have been implicitly authorized. And to the extent that there is not, to the extent we believe or don't care that our benevolence is not authorized by the benefactee, then these actions do acquire a moral taint. ${ }^{17}$

He also writes:

If we act without concern for [whether our help is welcome], or our concern for a person's good overrides concerns for whether the help is wanted, then I think it is plausible that there is something morally problematic about our action. The same point holds for gift giving and surprise parties: we typically take ourselves to have implicit authorization to do these things and if we really didn't think we did ... the practices start to look morally problematic. ${ }^{18}$

As I interpret Groll, the gift giver's attitude toward or belief about her implicit authorization at least partly (if not entirely) determines whether giving a gift is pro tanto morally objectionable. What it means for the gift giver to be implicitly authorized, however, is underspecified. As I read Groll, he seems to use the terms "authorization" and "welcome" interchangeably. As such, the gift giver's being implicitly authorized to give another a gift just means that the gift giver is implicitly welcome to do so.

Supposing this is the correct way to read Groll, the following view presents itself. 
View 1: If the gift recipient's right to self-beneficence is impermissibly infringed, then in acting only or primarily for his good, the gift giver either acts without concern for whether the gift is welcome or she believes that the gift is unwelcome.

If the consequent does not obtain, then it follows that the gift giver does not impermissibly infringe the gift recipient's right to self-beneficence. In an ordinary instance of gift giving, the gift giver usually believes that her gift is welcome. By believing so, she does not impermissibly infringe the gift recipient's right to self-beneficence.

It is worth registering a worry about View 1. The gift giver's attitude toward or belief about her authorization does not correctly explain in virtue of what she impermissibility infringes the gift recipient's right to self-beneficence. At best, the gift giver's lack of concern or belief that her gift is unwelcome explains why her act of gift giving is vicious. That the gift giver is not, as a matter of fact, implicitly authorized to give the gift recipient a gift, better explains in virtue of what she impermissibly infringes his right to self-beneficence.

This worry, though, is not devastating. Groll could simply accept this point and revise his view as follows.

View 2: If the gift recipient's right to self-beneficence is impermissibly infringed then in acting only or primarily for the gift recipient's good, the gift giver either acts without concern for whether the gift is welcome or she believes that the gift is unwelcome, and the gift is, in fact, unwelcome.

A more pressing worry for Groll is that, even when the gift giver believes that she is implicitly authorized and is implicitly authorized, she still permissibly infringes the gift recipient's right to self-beneficence. When a right is permissibly infringed, the infringer still has "residual obligations," such as to apologize to the person whose right is infringed. ${ }^{19}$ But this is the wrong result in ordinary instances of gift giving. To illustrate, consider the following example.

Gift Giving 1: Sam and Amy are co-workers. Sam has told Amy that he enjoys reading for leisure. Sam's birthday is tomorrow and Amy is confident that Sam will enjoy receiving a new book. So, Amy buys Sam a book and gives it to him for his birthday.

In this case, an apology does not seem called for. The best way to make sense of this case is to argue that Sam has waived his right to self-beneficence, and in doing so, has removed Amy's pro tanto duty not to act only or primarily for his good. 
But this move is not convincing. Sam has not expressly relieved Amy of her pro tanto duty. Furthermore, even if this right is sometimes waived within certain relational contexts, Sam's and Amy's relationship (i.e., co-workers) hardly seems like the sort of relational context in which Sam's right is waived.

\section{THE RIGHT AGAINST LEGITIMATE AGENCY INTERFERENCE}

Nevertheless, I agree that there is something morally problematic about giving a gift to a person who has made it clear that the gift is unwelcome. For illustrative purposes, consider the following case.

Gift Giving 2: Sam and Amy are co-workers. Sam tells Amy that he dislikes reading for leisure and does not want to be given a book for his upcoming birthday. Amy believes that Sam is missing out on the pleasures of reading and that if she gives him a book for his birthday he may come to enjoy reading more. So, despite Sam's wishes, Amy gives him a book for his birthday.

According to Groll, in giving Sam a book for his birthday, Amy impermissibly infringes his right to self-beneficence. However, this is not quite right. While Amy does act primarily for Sam's good in giving him a gift, she also takes over the legitimate exercise of his agency by ignoring his request that others not give him a book. Presumably, whether one is comfortable with receiving a certain gift is a decision that falls within one's sphere of legitimate agency. By taking over this matter, Amy wrongs Sam.

An important observation is that, in impermissible instances of gift giving, acting primarily for the gift recipient's good is often coextensive with the gift giver taking over the legitimate exercise of the gift recipient's agency. I suggest that the latter feature, rather than the former, explains why the gift giver acts wrongly. If the gift giver infringes a particular right of the recipient's, it is more plausibly a right that the gift recipient has against others taking over the legitimate exercise of his agency. Hence, the right against legitimate agency interference.

For present purposes, a person's sphere of legitimate agency should be understood as a sphere in which he has legitimate control over the matters that fall within it. A competent adult has legitimate control over these matters insofar as he has a claim right against others taking over these matters. A person legitimately exercises his agency when he makes decisions pertaining to matters that fall within this sphere. Like the right to self-beneficence, the proposed right should be understood as a pro tanto claim right. A competent adult has a pro tanto duty not to take over the legitimate exercise of another's agency. 
A full account of a competent adult's sphere of legitimate agency is beyond the scope of this note. However, following Jessica Begon, I suggest that Martha Nussbaum's influential list of central capabilities can provide us with a helpful starting point. ${ }^{20}$ Matters pertaining to a person's mental and physical health, body, education, play/recreation, intimacy/intimate relationships, religious and political affiliation(s), conception of the good, identity, and property/personal possessions contribute to a person living a flourishing life. ${ }^{21}$ As such, decisions pertaining to each of these matters plausibly fall within a person's sphere of legitimate agency.

The right against legitimate agency interference more plausibly explains why hard paternalism is pro tanto wrong. Like instances of impermissible gift giving, in instances of hard paternalism, the paternalist acting primarily for the good of the recipient is coextensive with the paternalist taking over the legitimate exercise of his agency. This latter feature better explains why hard paternalism almost always involves a rights infringement and, consequently, why it is pro tanto wrong.

Additionally, the right against legitimate agency interference does not imply that the gift giver, in ordinary instances of gift giving, permissibly infringes the gift recipient's right. Given that these instances do not ordinarily involve the gift giver taking over the legitimate exercise of the gift recipient's agency, the gift giver neither permissibly nor impermissibly infringes his right.

\section{CONCLUSION}

Recall the case of Rob's Keys. On Groll's view, Rob acts wrongly in hiding his keys from Fatima in virtue of infringing her right to self-beneficence. This is not the correct explanation. Presumably choices involving Fatima's hearing are hers to make, and her choice is to ignore the recommendations of her doctors. By hiding his car keys from her, Rob interferes with the legitimate exercise of her agency, thereby infringing her right against legitimate agency interference. If hard paternalism is pro tanto wrong in virtue of always infringing a right, it is a competent adult's right against legitimate agency interference. ${ }^{22}$

University of Wisconsin-Madison sheintul@wisc.edu

See Begon, Policy without Paternalism, 66-70.

See Nussbaum, Women and Human Development, 78-80.

I am indebted to Steven Norris and two anonymous reviewers for invaluable feedback on this paper. I also want to thank Harry Brighouse for encouraging me to write this paper, Lisa Tessman for her unwavering support of my work on paternalism, and several members of 


\section{REFERENCES}

Begon, Jessica. "Paternalism." Analysis 77, no. 3 (July 2016): 355-73.

- "Policy without Paternalism: A Capability Approach to Legitimate State Action." PhD dissertation, 2013. https://etheses.whiterose.ac.uk/5412/.

Feinberg, Joel. The Moral Limits of the Criminal Law. Vol. 7, Harm to Self. New York: Oxford University Press, 1986.

Frederick, Danny. "Pro-Tanto Versus Absolute Rights." Philosophical Forum 45 (December 2014): 375-94.

Groll, Daniel. "Paternalism and Rights." In The Routledge Handbook of the Philosophy of Paternalism, edited by Kalle Grill and Jason Hanna, 119-30. New York: Routledge, 2018.

Hohfeld, Wesley. Fundamental Legal Conceptions. New Haven: Yale University Press, 1919.

Mill, John Stuart. On Liberty. Indianapolis: Hackett, 1978.

Nussbaum, Martha. Women and Human Development: The Capabilities Approach. Cambridge: Cambridge University Press, 2000.

Shiffrin, Seana. "Paternalism, Unconscionability Doctrine, and Accommodation." Philosophy and Public Affairs 29, no. 3 (Summer 2000): 205-50.

Thomson, Judith Jarvis. The Realm of Rights. Cambridge, MA: Harvard University Press, 1990.

Tsai, George. "Rational Persuasion as Paternalism." Philosophy and Public Affairs 42, no. 1 (April 2014): 78-112.

the Human Development and Capabilities Association (HDCA) for advising me to continue writing on paternalism both within and outside of the context of the capabilities approach. 